\title{
Schoenberg as a Performing Artist
}

Translator's note. The violinist Rudolf Kolisch was brother-in-law of Arnold Schoenberg. He first played under Schoenberg's direction in the Verein für musikalische Privatauffulirungen. Through the Kolisch Quartet, founded in 1922 on Schoenberg's instigation, and later in America, through the Pro Arte Quartet, he promoted the music of the Second Vicnnese School. Kolisch's essay was originally published in German as 'Schönberg als nachschaffender Künstler' in the issue of Musikblätter des Anbruch commemorating Schoenberg's fifticth birthday (6 [August-September 1924], 306-7); this is the first English translation. Kolisch's text presents ideas about the rendering of ideas: it is essentially philosophical, and as such, many would argue, untranslatable. There are no English equivalents for many of its terms. With this proviso, the translation is offered as a guide to the original. In those instances where recurrences of words in the original are not preserved in the translation and where it was felt that important nuances of the original were lost, the German has been added in parentheses. In this regard the words used by Kolisch to denote 'performance' are particularly varied: 'nachschaffen' ('to reproduce'); 'vortragen' (lit. 'to carry forward', hence 'to hold forth', 'to execute'; Kolisch used 'declamation' as a synonym for 'Vortrag' when referring to the way in which a specific musical passage is conceived and executed); 'aufführen' ('to perform'); 'reproduzieren' (the latinate equivalent for the German 'nachschaffen'); 'darstellen' ('to represent'); 'Wiedergabe' ('rendition'); 'spielen' ('to play'); and 'musizieren' ('to play', 'to makc music'). Some of the connotations of the word 'nachschaffen' from the original title of Kolisch's article are captured by Erwin Stein in the Introduction to his Form and Performance: 'Music consists of sounds, and the word "form", applied to music, means the arrangement of sounds. Per-formance, then, is the realization of particular sounds in a particular order' (London: Faber, 1962; repr. New York: Limelight Editions, 1989, p.17). I would like to thank Reinhard Kapp and David Satz for their suggestions concerning the translation.

Neil Boynton

He has his own physiognomy here too. One can guess how he stands with regard to the problem of performance (Vortrag) just from the idiosyncratic care with which he notates his works. There is certainly no other person in the entire realm of today's music business who brings such a high understanding of art and such a relentless exactitude to bear on the work. That aside,
Schoenberg's manner of performing (reproduzieren) has a special character. It is guided by the mind and not by sentimentality; it is full of ideas and not of feelings. The work of art is represented in performance in accordance with its construction; the relations of its parts to each other is revealed from the contemplation of the whole. For Schoenberg, it is not a mood that ought to be brought to expression, but rather a musical idea. It is not the feeling of the performer (Aufführender) that ought to be shown, but rather a theme, which perhaps contains this feeling. The musical shape (Gestalt) is reconstructed, not some sort of soundpainting. All technical means of performance (Vortrag) are put at the service of the musical idea without drawing upon associations from the realm of the emotions. One of Schoenberg's technical instructions often says more about the essence of performance (Vortrag) than volumes of aesthetics.

Through the manner of its representation in performance, every phrase is adapted to its proper function in the organism of the musical work of art. Every phrase performs just this function in the work itself a priori of physical performance and in this sense Schoenberg's representation is objective throughout, as he grants each note only the place which is proper to it according to the construction of the work. But to comprehend the latter in all of its details such that one knows the former, that is the task of the performing (darstellend) subject with respect to the object of the work of art.

The organization of a work is elucidated by a punctuation which not only separates the main sections, but also makes clear the end of every phrase, brings about the combining of several phrases into a larger musical structure, putting the latter with another by contrast and by superand subordination. The punctuation fulfils here therefore a similar task as in speech; it reveals the analogy between musical and literary works of art, and he who is acquainted with Schoenberg's prose, will be able to imagine how well-informed he is about these things. (Schoenberg makes drastic use of this analogy when he says of someone who performs (vortragerl) a piece of 
music without taking into account its organization, that he plays (musizieren) the way a Bohemian cooker-woman speaks.)

The most surprising thing about Schoenberg's representation of musical works in performance is, however, that this analysis made manifest is at the same time the most lively playing. The liveliness does not result from the customary external vitality (which is indeed merely the overemphasis of the zestful elements of a piece, mostly at the expense of the structural balance of its performance), but rather it results from the fantasy, from the intellectual vitality, from the intensity with which every figure (Gestalt) is given its characteristic form.

The musical power of imagination of Schoenberg is so intense that he forces the sound which he has imagined even beyond all instrumental technique, and - a wonder that is often to be seen - demonstrates how to play it to the helpless instrumentalist. What a triumph of fantasy over technique!

The structural balance of the work of art corresponds to that of its representation. His most sensitive feeling for form reacts to the slightest violations against it, and regulates the relationship of tempi through tempo-transformation ('Tempoverwandlung'), as well as determining the degree of accelerando and ritardando.
The force which is effective in the structuring of successive events also orders simultaneously sounding voices. Polyphony is thereby represented in performance by playing each voice with the expression appropriate to it, that is by playing with the appropriate character. There is not therefore the absolute withdrawal of one voice behind the other, rather all are made audible by being given character. The art with which the seemingly formulaic accompanying voices of the classical composers come to life, whereby their latent polyphony manifests itself, is wonderful. Above all, whilst a complete understanding helps to bring clarity to the apparently complicated structure of modern music, it reveals undreamedof depths within the seeming simplicity of classical music. As regards the latter, this is also where the originality of Schoenberg's representation of works in performance is most strikingly proven. As it is based directly on the contemplation of the work of art, it is not dependent on tradition. For Schoenberg all instructions are contained in the notes themselves - one only has to be able to read them properly. He knows how to produce the wealth of ideas which he crams into his notes from those of the old masters - he is their most ingenious interpreter! His spiritual affinity with them is obvious from his renditions (Wiedergabe) of their works.

\section{Conference Report}

'Dic Lehre von der musikalischen Aufführung in der Wiener Schule', 3-6 April 1995, Wiener Konzerthaus

The programme of the recent symposium on the performance practice of the Second Viennese School emanated in large part from topics inherent in Kolisch's gnomic account of Schoenberg's approach to performance, reproduced above. Reinhard Kapp, the symposium director (ably assisted by Markus Grassl and Sigrid Wiesmann) has over the years done much to unravel the plethora of ideas contained in this brief exposition (see inter alia, 'Rudolf Kolisch die Konstruktion des Wiener Espressivo', in Österreichische Musiker im Exil: Kolloquium $1988 \mathrm{ed}$. by Monica Wildauer, Beitrage der Österreichischen Gesellschaft für Musik, 8 [Kassel: Bärenreiter, 1990], pp.102-110). And in many ways the symposium represents the latest instalment in an ongoing project to evaluate the performance activities of Schoenberg and his circle: chief among the documentary evidence are the papers of Kolisch, which Kapp is editing in association with Regina Busch (Vienna) and Károly Csipák (Berlin).

The kernel of Schoenberg's performance practice is the idea that one must learn to read the music properly: the practical manifestation of this can be heard in Kolisch's recordings, and might be characterized as a more objective reading of the score. For Kolisch, the rehabilitation of music in performance with respect to contemporary practice required both 'Détoscanimisation' (the purging of meaningless objectification) as well as 'Entschnabelung' (the purging of meaningless subjectification). Participants of the symposium were able to hear a private recording of Webern's String Trio op. 20 performed by Kolisch with Lorna Manfred (viola) and Lowell Creitz (cello) at a specially created listening station, which also boasted recordings of Steuermann playing Schoenberg's Six Little Piano Pieces op.19 and Webern conducting choral music by Brahms 